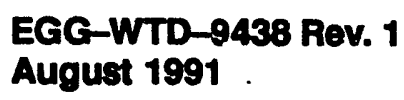

INFORMAL REPORT

\title{
A BRIEF ANALYSIS AND DESCRIPTION OF TRANSURANIC WASTES IN THE SUBSURFACE DISPOSAL AREA OF THE RADIOACTIVE WASTE MANAGEMENT COMPLEX AT INEL
}

\author{
D. A. Arrenholz \\ J. L. Knight
}

Managed

by the U.S.

Department

of Energy

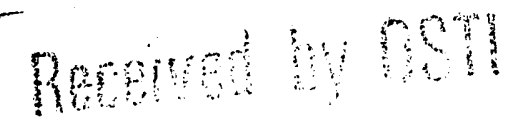

NOV 221991

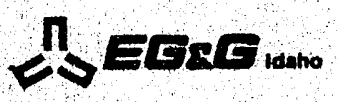

Work performed under DOE Contract No. DE-ACO7-761D01570 
This document contains new concepts or the author(s) interpretation of new calculations and/or measurements; accordingly. EG\&G Idaho, Inc. is required by the United States Government to include the following disclaimer:

\section{DISCLAIMER}

This report was prepared as an account of work sponsored by an agency of the Uivited States Govermment. Neither the United States Govemment nor any agency thereof, nor any of their employees, makes any warranty, express or implied, or assumes any legal liability or responsibility for the accuracy, completeness, or usefulness of any information, apparatus, product or process disctosed, or represents that its use would not intringe privately owned rights. References herein to any specitic commercial product, process, or service by trade name, trademark, manufacturer, or otherwise, does not necessarily constitute of imply its endorsement, recommendation, or favoring by the United States Govemment or any agency thereof. The views and opinions of authors expressed herein do not necessarily state or reflect those of the United States Covernment or any agency thereof. 


\section{A BRIEF ANALYSIS AND DESCRIPTION OF TRANSURANIC WASTES IN THE SUBSURFACE DISPOSAL AREA OF THE RADIOACTIVE WASTE MANAGEMENT COMPLEX AT INEL}

D. A. Arrenholz

J. L. Knight

Published August 1991
Idaho National Engineering Laboratory
EG\&G Idaho, Inc. Idaho Falls, ID 83415

Prepared for the

U.S. Department of Energy

Field office, Idaho

Under DOE Contract No. DE-AC07-76ID01570 
A BRIEF ANALYSIS AND DESCRIPTION OF TRANSURANIC WASTES IN THE SUBSURFACE DISPOSAL AREA OF THE RADIOACTIVE WASTE MANAGEMENT COMPLEX AT INEL

EGG-WTD-9438

Rev. 1

August 1991

Approved by:

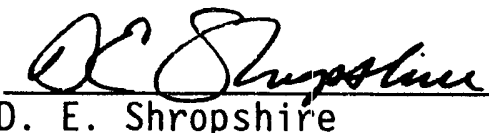

$\frac{8-9-91}{\text { Date }}$

Prepared by:
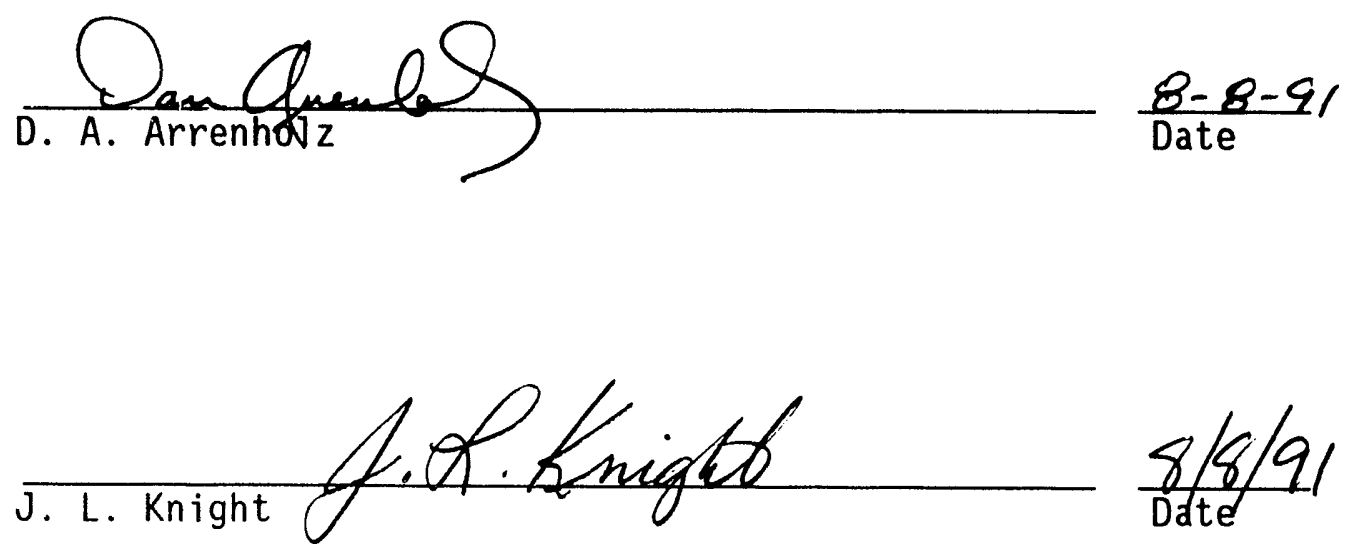


\begin{abstract}
This document presents a brief summary of the wastes and waste types disposed of in the transuranic contaminated portions of the Subsurface Disposal Area during the period 1954 through 1970. Wastes included in this summary are organics, inorganics, metals, radionuclides, and atypical wastes. In addition to summarizing amounts of wastes disposed and describing the wastes, the document also provides information on disposal pit and trench dimensions and contaminated soil volumes. The report also points out discrepancies that exist in available documentation regarding waste and soil volumes and makes recommendations for future efforts at waste characterization.
\end{abstract}




\section{SUMMARY}

This document presents a brief summary of the wastes and waste types disposed of in the Subsurface Disposal Area (SDA) at the Radioactive Waste Management Complex. The information presented in this report was compiled through the review of existing documents and is limited to the transuranic waste containing portions of the SDA, Pits 1 through 6, 9, and 10 and trenches 1 through 10. In addition to describing the wastes and disposal locations, several discrepancies among currently available documents are pointed out, and recommendations for future efforts aimed at characterizing the wastes are made. 
ABSTRACT .............................

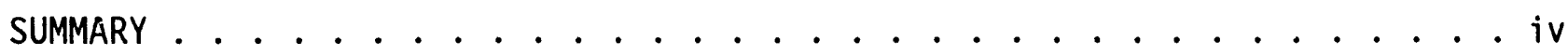

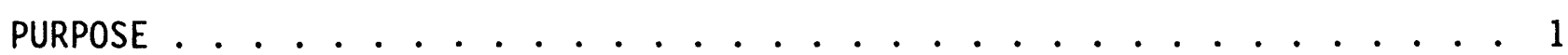

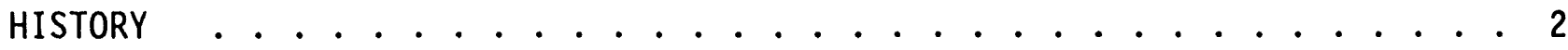

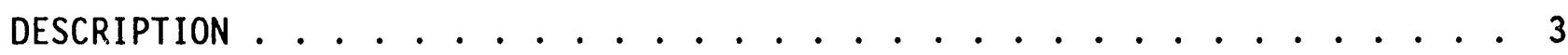

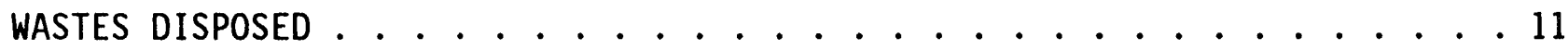

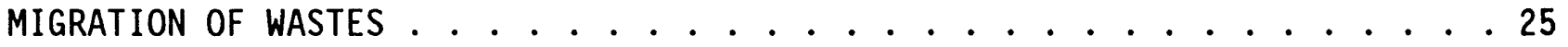
ASSUMPTIONS . . . . . . . . . . . . . . . . . . . . . 29

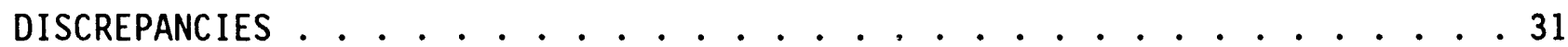

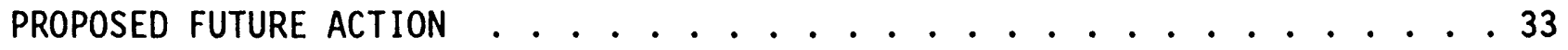

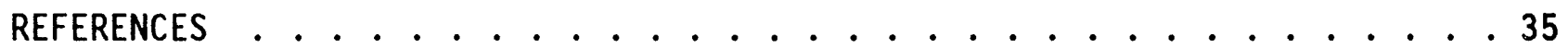

\section{FIGURES}

1. Map of the SDA and RWMC at INEL .............. 4

2. Conceptual model of radionuclide and hazardous contaminant migration at the SDA . . . . . . . . . . . 27

3. Conceptual model of volatile organic chernical contaminant migration at the SDA . . . . . . . . . . 28

\section{TABLES}

1. Summary of volumes of pits, trenches, wastes, and associated soils in selected pits and trenches at the SDA .................... 5

2. Excavation details for selected pits at the SDA ........ 6

3. Excavation details for selected trenches at the SDA . . . . . . 7 
4. Various physical characteristics of soil and sediment samples from the RWMC wells................. . 8

5. Properties of soil and sediment samples from the RWMC wells......................... 8

6. Particle size distribution for subpit samples . . . . . . . . . 9

7. Mineralogy for subpit samples . . . . . . . . . . . . . . 9

8. Clay mineralogy of selected surficial sediment samples . . . . . 10

9. Summary listing of makeup of waste buried in the SDA at RWMC ........................ 12

10. Waste Constituants Disposed in Rocky Flats TRU pits and Trenches at the SDA ................... 13

11. Weight and voiume fractions of wastes stored at the RWMC

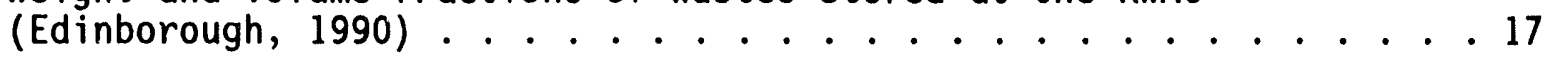

12. Waste container types, numbers, and total volumes for selected pits at the SDA .................. 18

13. Waste container types, numbers, and total volumes for selected trenches at the SDA . . . . . . . . . . . . . 19

14. Special waste considerations buried in pits at the SDA . . . . . 20

15. Volumes of organic wastes shipped from RFP to the INEL . . . . . . 21

16. Estimates of metal content in selected pits and trenches at the SDA..................... 22

17. Summary of contaminants and environmental media of concern ..........................26 


\title{
A BRIEF ANALYSIS AND DESCRIPTION OF TRANSURANIC WASTES IN THE SUBSURFACE DISPOSAL AREA OF THE RADIOACTIVE WASTE MANAGEMENT COMPLEX AT INEL
}

\begin{abstract}
PURPOSE
The purpose of this report is to provide a brief overview and summary of the waste forms, types, and amounts buried in the Subsurface Disposal Area (SDA) at the Radioactive Waste Management Complex (RWMC) from 1952 to 1970. This document was prepared for use as necessary by programs within the EG\&G Idaho, Inc., Waste Technology Development Department, other EG\&G Idaho organizations, and outside organizations interested in demonstrating potential remedial technologies at the SDA.
\end{abstract}




\section{HISTORY}

The RWMC was established in 1952 for the disposal of wastes generated at the National Reactor Testing Station (NRTS, now known as Idaho National Engineering Laboratory); wastes were later received from a variety of sources, including government agencies, universities, and research laboratories. From 1952 to 1970 wastes consisting of solid wastes (Vigil, 1989), transuranic (TRU) contaminated wastes (Barnes et al., 1989) ${ }^{\mathrm{a}}$, and low-level wastes (LLW) ${ }^{\mathrm{b}}$ were buried in a series of pits and trenches located in the area now known as the SDA.

Originally, these wastes were not segregated at the time of disposal; however, TRU wastes were generally placed in the pits, while LLWs were generally placed in the trenches. In 1970, above ground storage of TRU contaminated waste was initiated at the Transuranic Storage Area (TSA) at the RWMC. Currently, pit disposal at the SDA is utilized for LLWs only; trenches are no longer used for waste disposal.

a. For the purpose of this report TRU wastes are considered to be those wastes that are contaminated with alpha-emitting radionuclides that are heavier that uranium (atomic weight 92), have half-lives longer than 20 years, and are in concentrations greater than 10 nanocuries per gram.

b. LLW is defined as waste not classified as high-level radioactive waste, transuramic waste, spent nuclear fuel, or byproduct material as defined in section 1le. (2) of the Atomic Energy Act (uranium or thorium tailings or waste). 


\section{DESCRIPTION}

TRU wastes were disposed at the SDA in Pits 1 through $6,9,10,11$, and 12 and in Trenches 1 through 10 (refer to Figure 1 for details) and in 1 imited amounts in Trenches 16 through 54 (Horton, 1988). During earlier retrieval efforts (circa, 1978) the drummed wastes in pits 11 and 12 were removed (McKinley and McKinney, 1978); however, some wastes contained in boxes were left in the pits due to the deteriorated condition of the boxes (Horton, 1988). Pits 7 and 8 were used for the disposal of non-TRU wastes only (Card, 1977). Trenches were generally excavated to bedrock (basalt), approximately $10 \mathrm{ft}$ down and averaged about $7 \mathrm{ft}$ wide and up to $1800 \mathrm{ft}$ long. Pits were excavated to bedrock and generally backfilled with 2 to $5 \mathrm{ft}$ of soil to provide a level floor (Guay, 1989). Surface areas and volumes of the pits varied widely.

Following excavation, wastes were deposited into the pits and trenches. From 1952 until 1963, the waste containers (mainly steel drums and wooden and cardboard boxes) were stacked to optimize disposal space. From 1963 until 1969, the wastes were randomly dumped into the pits and trenches in order to 1 imit worker radiation exposure. Beginning in 1969, the wastes containers were stacked in order to optimize disposal volume. Following emplacement of the wastes, the pits and trenches were backfilled and covered with at least 3 $\mathrm{ft}$ of the silty clay soil (Guay, 1989).

Excavated volumes of the pits and trenches are siven in Table 1 , Guay, 1989). This table also includes the estimated volumes of soils placed in the pits and trenches as intermediate cover during placement of the wastes, backfilling of the pits and trenches, overburden placed after closure, and, in the case of the pits, underburden beneath the pits. Volumes of wastes disposed in the pits and trenches are also given. Excavation details of the individual pits and trenches are given in Tables 2 and 3.

The soils at the RWMC consist mainly of silty clays and sands. Details of the characteristics of INEL soils are presented in Tables 4 through 8. 


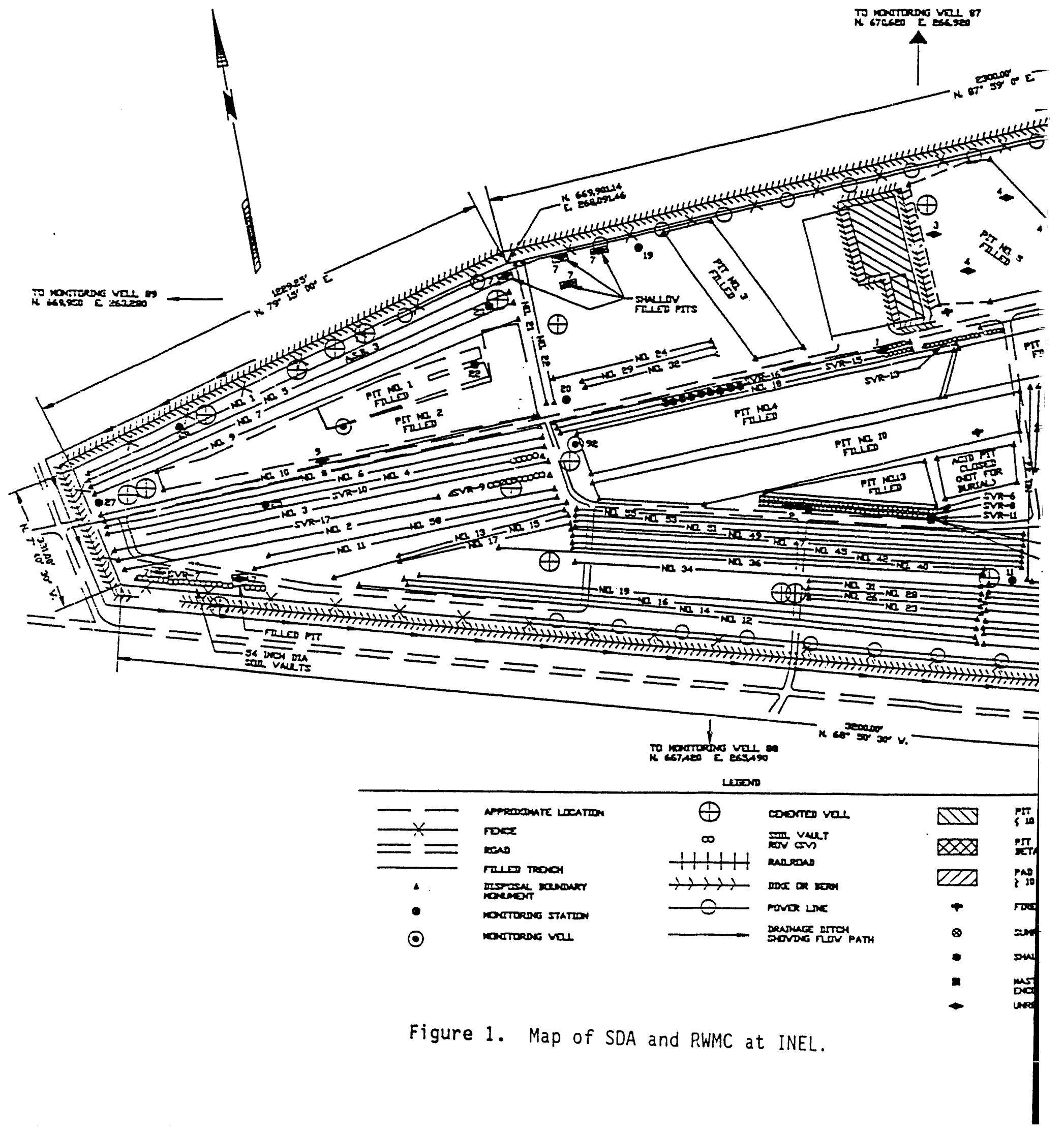




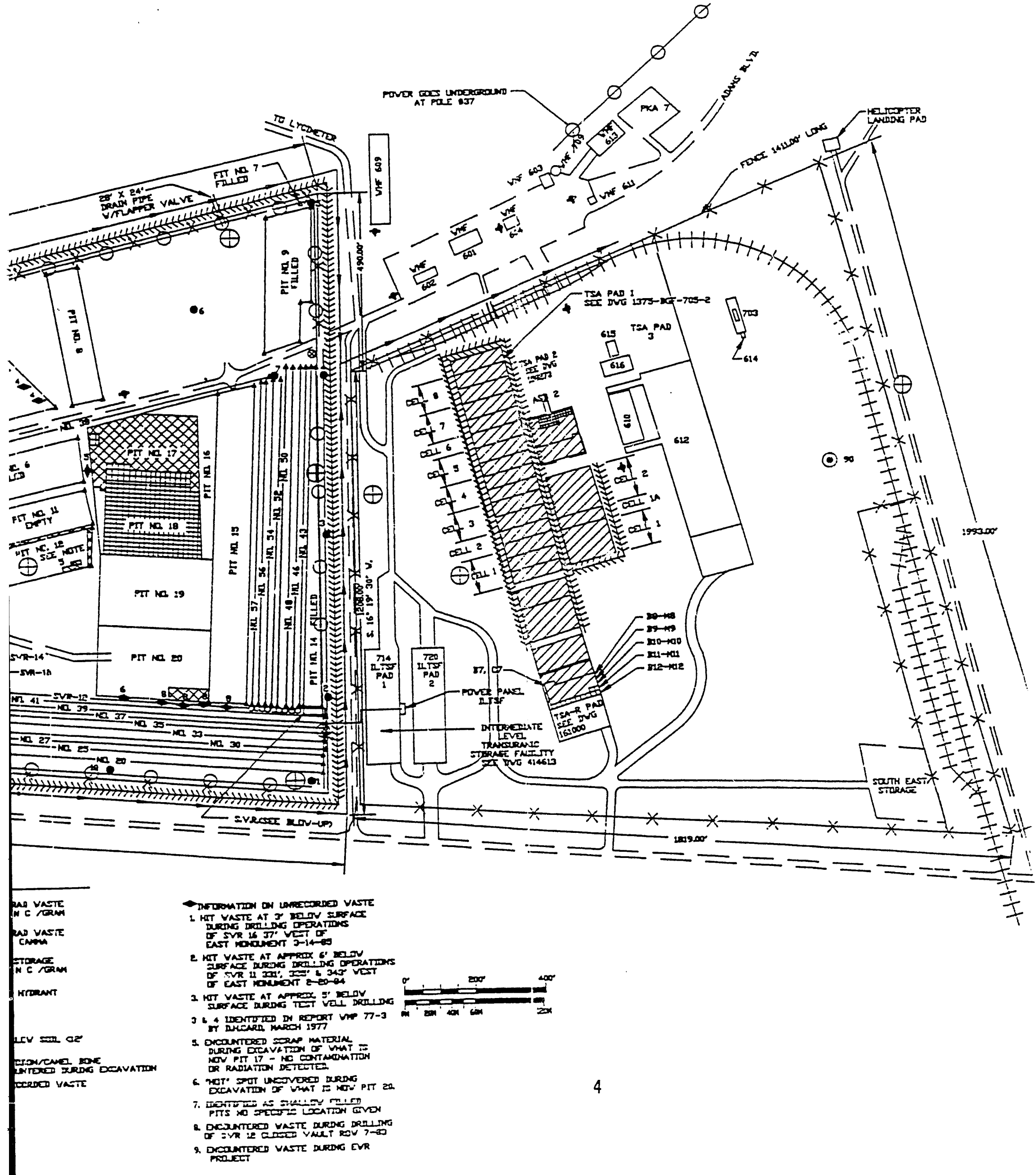




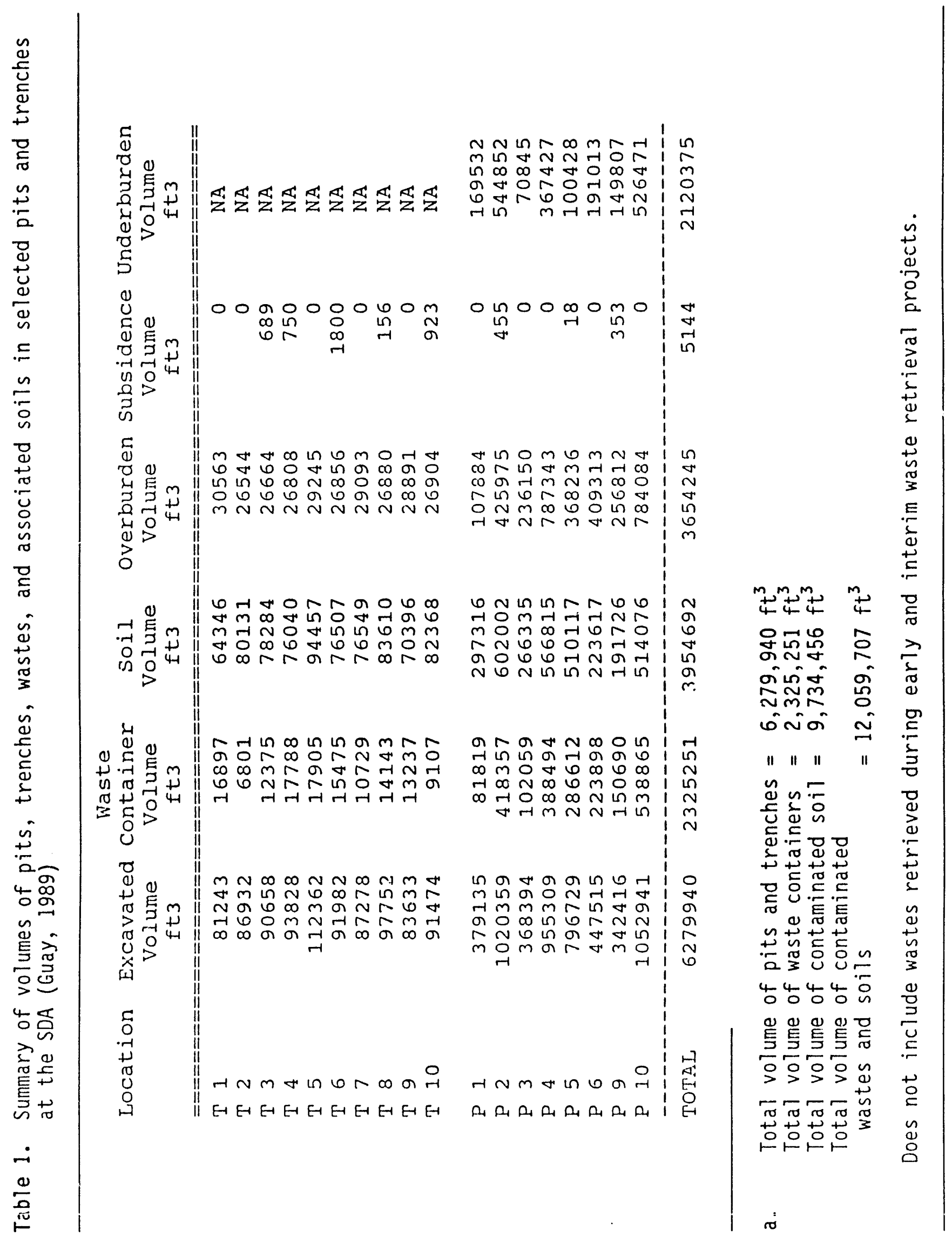




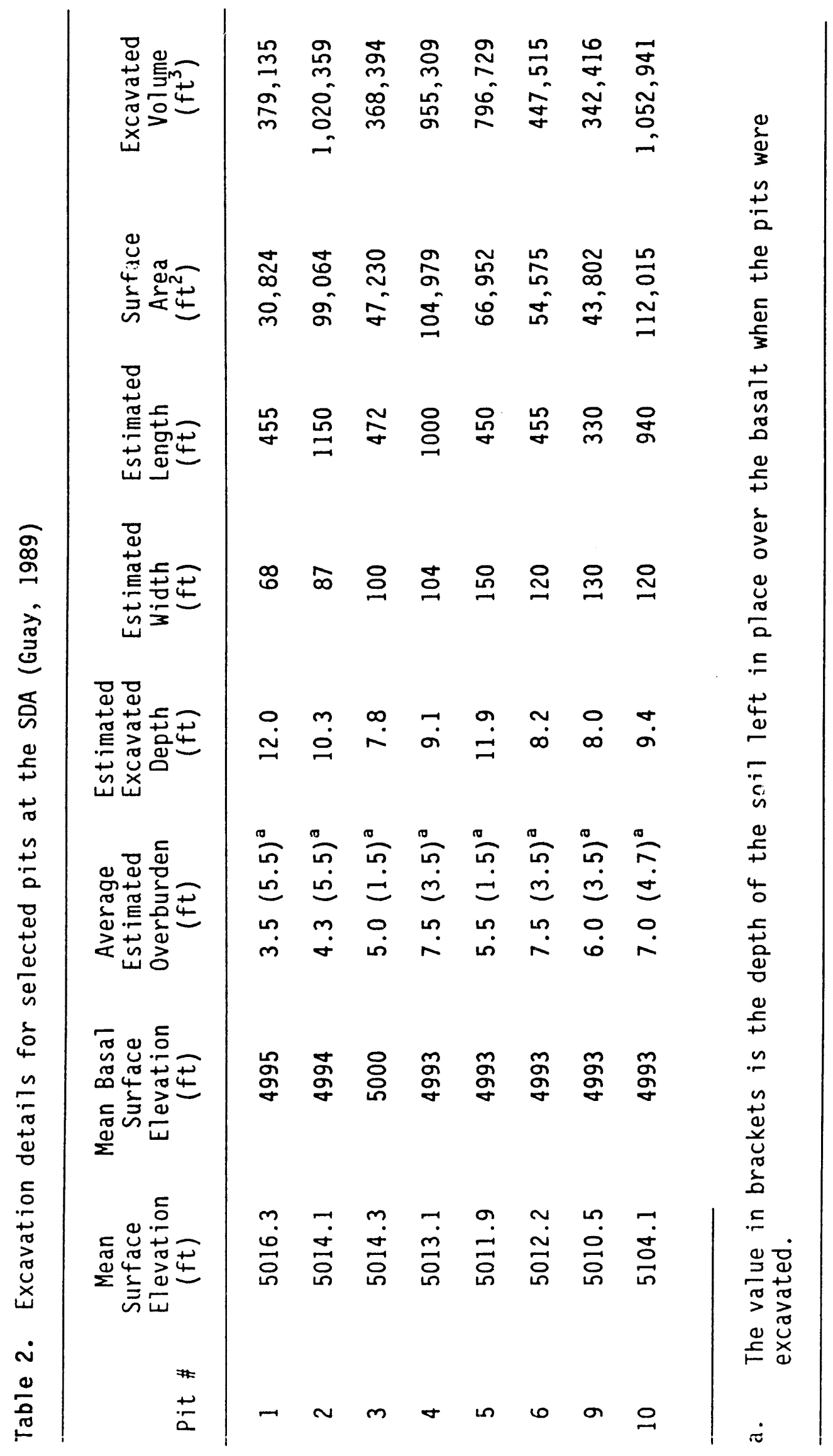




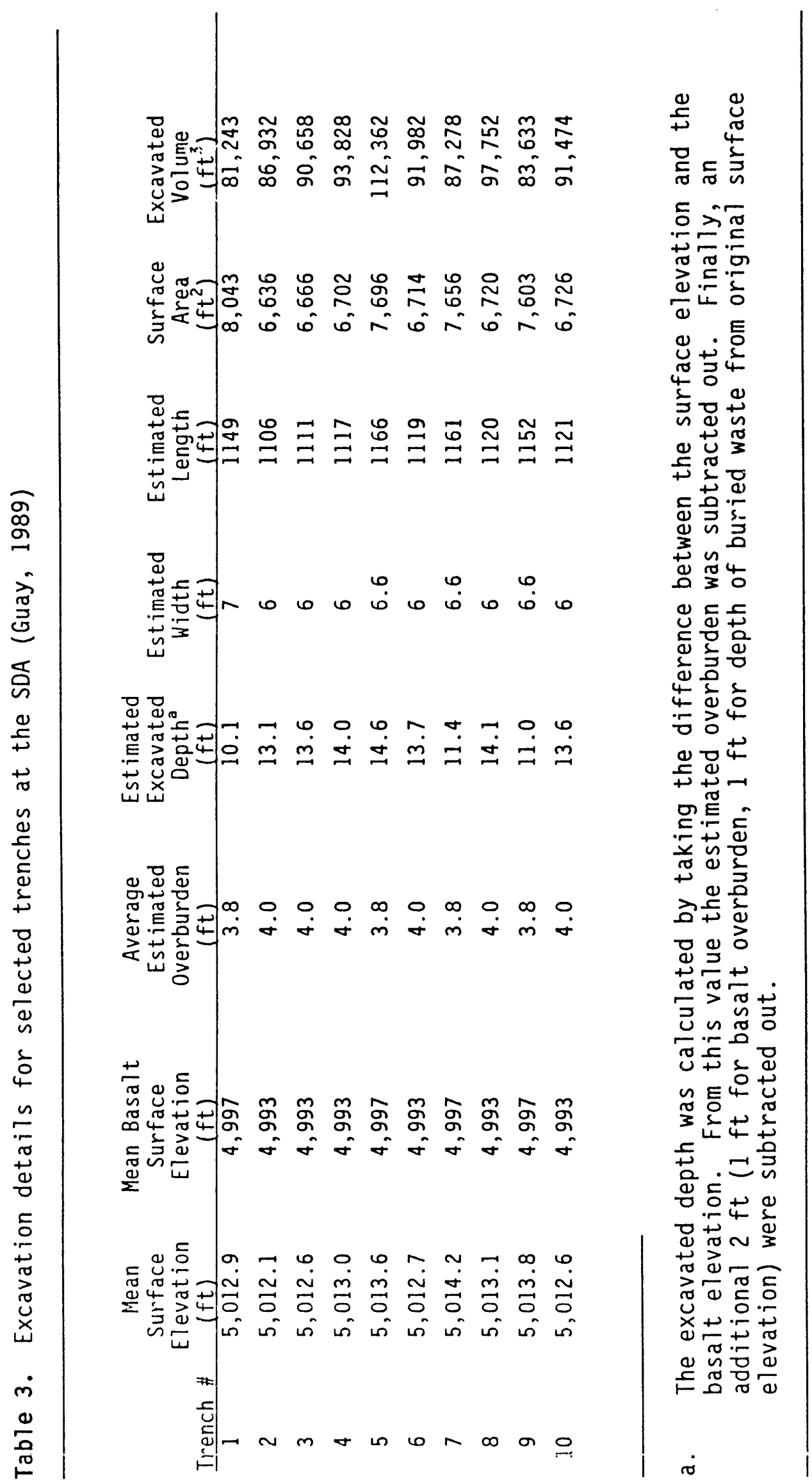


Table 4. Various Physical Characteristics of Soil and Sediment Samples from the RWMC Wells (EG\&G Idaho 1989)

\begin{tabular}{|c|c|c|c|c|c|c|c|c|c|}
\hline $\begin{array}{l}\text { Well } \\
\text { No. }\end{array}$ & $\begin{array}{r}\text { Der } \\
\mathrm{Tol} \\
\mathrm{ft}\end{array}$ & $\begin{array}{l}\text { pth } \\
\text { in.) }\end{array}$ & $\begin{array}{l}\text { inter } \\
\text { Bot } \\
(\mathrm{ft}\end{array}$ & $\begin{array}{l}\text { val } \\
\text { tom! } \\
\text { in.) }\end{array}$ & $\begin{array}{r}\text { Specific } \\
\text { Gravity }\end{array}$ & $\begin{array}{c}\text { Bulk } \\
\text { Density } \\
\left(\mathrm{g} / \mathrm{cm}^{3}\right)\end{array}$ & $\begin{array}{l}\text { Porosity } \\
\text { (percent) }\end{array}$ & $\begin{array}{c}\text { Moisture } \\
\text { Content } \\
\text { (Dercent) }\end{array}$ & $\begin{array}{c}\text { Vertical } \\
\text { Hydraul ic } \\
\text { Conduct } \\
\text { (m/day) }\end{array}$ \\
\hline 92 & 2 & 6 & 5 & & 2.65 & 1.87 & 34.3 & 12.9 & $5.5 \times 10^{-4}$ \\
\hline 94 & 6 & 6 & 8 & 3 & 2.67 & 2.02 & 30.5 & 16.4 & $2.7 \times 10^{-4}$ \\
\hline 95 & 10 & & 12 & 6 & 2.66 & 1.70 & 41.0 & 13.2 & $7.9 \times 10^{-3}$ \\
\hline
\end{tabular}

Table 5. Properties of soil and sediment samples from the RWMC wells (EG\&G Idaho, 1989)

\begin{tabular}{|c|c|c|c|c|c|c|c|c|c|c|c|}
\hline \multirow[b]{2}{*}{$\begin{array}{l}\text { Well } \\
\text { No. }\end{array}$} & \multicolumn{4}{|c|}{ Depth Interval } & \multirow{2}{*}{\multicolumn{3}{|c|}{$\begin{array}{l}\text { Particle Size } \\
\text { Distribution }(\%)^{a}\end{array}$}} & \multicolumn{3}{|c|}{ Clay Minerals $(\%)$ Moisture } & \multirow{2}{*}{$\begin{array}{c}\text { Cation Exchange } \\
\text { Capacity } \\
\text { (meg/100g) }\end{array}$} \\
\hline & $\begin{array}{l}\text { Top } \\
\text { (ft }\end{array}$ & in) & $\begin{array}{l}\text { Bott } \\
\text { (ft }\end{array}$ & om & & & & $\begin{array}{c}\text { Kaolin- } \\
\text { ite }\end{array}$ & Illite & $\begin{array}{l}\text { Montmor- } \\
\text { illonite }\end{array}$ & \\
\hline$\overline{92}$ & 2 & 6 & 5 & & 21.2 & 48.8 & 30.1 & 2 & 5 & 5 & 14 \\
\hline 94 & 6 & 6 & 8 & 3 & 38.7 & 56.5 & 4.8 & 3 & 9 & 4 & 23 \\
\hline 95 & 10 & & 12 & 6 & 38.5 & 55.6 & 5.9 & 1 & 4 & 3 & 17 \\
\hline Median ${ }^{b}$ & & & & & 35.9 & 56.0 & 7.3 & 2 & 7 & 6 & 21 \\
\hline
\end{tabular}

\footnotetext{
a. $\quad$ Clay $<0.004 \mathrm{~mm}$

Silt $0.004-0.062 \mathrm{~mm}$

Sand $0.062-<2.00 \mathrm{~mm}$.

b. Median of eight samples.
} 
Table 6. Particle size distribution for subpit samples (in percent of analyzed sample ${ }^{a}$ ) (EG\&G Idaho, 1989)

\begin{tabular}{|c|c|c|c|c|c|c|c|}
\hline $\begin{array}{l}\text { Sample } e^{b} \\
\text { Number }\end{array}$ & $\begin{array}{l}\text { Depth } \\
\text { (in meters) }\end{array}$ & $\begin{array}{l}\text { C1ay } \\
<0.004 \\
\mathrm{~mm}\end{array}$ & $\begin{array}{c}\mathrm{Si1t} \\
0.004- \\
0.0625 \\
\mathrm{~mm}\end{array}$ & $\begin{array}{c}\text { Sand } \\
\text { Very } \\
\text { Fine } \\
0.0625- \\
0.125 \mathrm{~mm}\end{array}$ & $\begin{array}{l}\text { Sand } \\
\text { Fine } \\
0.125- \\
0.25 \mathrm{~mm}\end{array}$ & $\begin{array}{l}\text { Sand } \\
\text { Medium } \\
0.25- \\
0.5 \mathrm{~mm}\end{array}$ & $\begin{array}{l}\text { Sand } \\
\text { Coarse } \\
0.5-1 \mathrm{~mm}\end{array}$ \\
\hline EWR-1-4 & 0.91 & 53.3 & 38.5 & 4.8 & 2.3 & 0.9 & 0.1 \\
\hline EWR-1-3 & 1.22 & 41.0 & 30.1 & 11.0 & 17.7 & 0.2 & 0 \\
\hline EWR-1-2 & 1.52 & 54.7 & 40.1 & 4.1 & 0.7 & 0.2 & 0.1 \\
\hline EWR-1-1 & 1.83 & 23.5 & 69.8 & 6.0 & 0.6 & 0 & 0.1 \\
\hline a. & \multicolumn{7}{|c|}{ Analyzed by the USGS Hydrologic Laboratory, Denver, Colorado. } \\
\hline c. & \multicolumn{7}{|c|}{ No particles coarser than $1 \mathrm{~mm}$ observed. } \\
\hline
\end{tabular}

Table 7. Mineralogy for subpit samples (in percent of analyzed sample) ${ }^{a}$ (EG\&G Idaho, 1989)

\begin{tabular}{ccccccccc}
$\begin{array}{c}\text { Sampleb } \\
\text { Number }\end{array}$ & $\begin{array}{c}\text { Depth } \\
\text { (in meters) }\end{array}$ & Quartz & $\begin{array}{c}\text { Potassium } \\
\text { Feldspar }\end{array}$ & Playioclase Calcite & $\begin{array}{c}\text { Pryoxene } \\
\text { Dioxide }\end{array}$ & $\begin{array}{c}\text { Clay Minerals } \\
\text { Percent }\end{array}$ \\
\hline EWR-1-4 & 0.91 & 27 & $\leq 5$ & 11 & 1 & 4 & 70 & $113+^{c}$ \\
EWR-1-3 & 1.22 & 29 & $\leq 6$ & 10 & 0 & 9 & 55 & $103+$ \\
EWR-1-2 & 1.52 & 15 & $\leq 3$ & 6 & 41 & $\leq 9$ & 25 & $87+$ \\
[WR-1-1 & 1.83 & 29 & 5 & 12 & 13 & $\leq 9$ & 40 & $99+$
\end{tabular}
a. Analyzed by the USGS Hydrologic Laboratory, Denver, Colorado.
b. All samples from surficial deposits.
c. Due to high percentage of clay mirierals. 
Table 8. Clay mineralogy of selected surficial sediment samples (in percent of total clay minerals/percent of original bulk samples) ${ }^{a}$ (EG\&G Idaho, 1989)

\begin{tabular}{|c|c|c|c|c|c|c|c|c|}
\hline Sample & $\begin{array}{l}\text { Depth } \\
\text { (in meters) }\end{array}$ & Chlorite & Illite & $\begin{array}{c}\text { Mixed Layer } \\
\text { Clays } \\
\text { (Illite/ } \\
\text { Smectite) }\end{array}$ & Smectite & Kaolinite & $\begin{array}{l}\text { Cation } \\
\text { Exchange } \\
\text { Capacity }\end{array}$ & $\begin{array}{c}\text { Carbonate } \\
\text { Content } \\
\left(\mathrm{CaCO}_{3}\right) \\
\text { Percent }\end{array}$ \\
\hline EWR-1-4 & 0.91 & $0 / 03$ & $6 / 25$ & $45 / 32$ & $13 / 9$ & $6 / 4$ & 27 & 0 \\
\hline EWR-1-3 & 1.22 & $0 / 03$ & $0 / 16$ & $48 / 26$ & $15 / 9$ & $6 / 3$ & 27 & 2.3 \\
\hline EWR - $1-2$ & 1.52 & $0 / 03$ & $6 / 9$ & $31 / 8$ & $24 / 6$ & $9 / 2$ & 11 & 36.1 \\
\hline EWR-1-1 & 1.83 & $0 / 03$ & $2 / 12$ & $30 / 12$ & $26 / 10$ & $12 / 5$ & 11 & 10.8 \\
\hline $\begin{array}{l}\text { a. } \\
\text { b. }\end{array}$ & \multicolumn{8}{|c|}{$\begin{array}{l}\text { Analyzed by the USGS Hydrologic Laboratory, Denver, Colorado. } \\
\text { In milliequivalents per } 100 \mathrm{~g} \text {. }\end{array}$} \\
\hline
\end{tabular}




\section{WASTES DISPOSED}

During the period 1954 to 1970 a wide variety of wastes and waste types were shipped to the SDA for disposal from on- and off-site generators. Table 9 presents a summary description of the makeup of the wastes buried at the SDA. Wastes of concern disposed of at the SDA include organics, inorganics, toxic metals, and radionuclides. Table 10 presents a listing of typical waste contaminants found at the SDA. A summary of the waste types buried at the SDA, giving weights and volumes, is presented in Table 11.

A variety of containers were utilized for the shipment of wastes to the SDA. These containers included steel drums (30, 40, and 55-gal), cardboard cartons, and wooden boxes (up to 105 in. $x 105$ in. $x 214$ in.). Larger individual items were disposed separately as loose trash. In addition, large amounts of plastic were used to line the containers and to wrap some of the boxes and most of the larger individual items. These plastics included polyethylene sheet plastic and drum liners, polyvinyl chloride sheets and liners, and plastic jugs and other contairers of unknown composition. Tables 12 and 13 present a breakdown of the number of containers disposed of in the pits and trenches, respectively, at the SDA during the period 1954 to 1970. Waste items that may present a particular challenge for remedial technologies are summarized by pit in Table 14 .

Nonradiological wastes of concern include primarily hazardous organics and various metals. Much of the organics were shipped to the SDA from off-site sources, particularly the Rocky flats Plant (RFP). An estimate of the amounts of various organic compounds shipped from RFP to the SDA is given in Table 15. Estimates of the amount of organics generated at INEL and disposed in the SDA are not available. Estimates of the amounts of metal disposed at the SDA have generally included only nontoxic metals. These metals are of concern due to the large amounts present in the pits and trenches at the SDA and the difficulties that they may present during remediation of the wastes contained a.t the SDA. Estimated metal content is presented by pit/trench in Table 16 . 
Table 9. Summary listing of makeup of waste buried in the SDA at RWMC (Mckinley, 1978)

Construction and Demolition Material

Laboratory Equipment and Materials

Process Equipment

Maintenance Equipment

Decontamination

Materials

Miscellaneous
Lumber, wallboari, concrete blocks, steel plate and shapes, ducting, electrical wires, fuse boxes, roofing material, floor tile, insulation, lead sheet and bricks, asphalt paving material, soil, sand, gravel, steel stairways, and ladders.

Hoods, laboratory benches, desks, chairs, cabinets, glassware, plastic tubing, plastic and glass bottles, solutions stabilized in concrete or plaster, and vermiculite.

Tanks, heat exchangers, tube bundles, condensers, pumps, piping, flanges, valves, organic wastes, ion exchange resins, zirconium plate, zirconium turnings, sawdust, and HEPA filters.

Hand tools, metal-working machines, cranes, hoists, welders, oils and grease, metal filings, and abrasive wheels and sheet.

Paper, rags, plastic bags and sheet, floor sweepings, brooms, and steel wool.

Sewer sludge, garbage, animal remains and excreta, jet engines, vehicles, Test Reactor Area fuel end boxes.

a. This listing is for the entire Subsurface Disposal Area (SDA). For the purpose of this document it is considered to be representative of the makeup of the TRU-contaminated waste. 
Table 10. Waste Constituants Disposed in Rocky Flats TRU Pits and Trenches at the SDA

Radionuclides

Aluminum isotopes

Americium-241

Calcium-45

Cal ifornium

Carbon-14

Cerium-144 (as $\mathrm{CeCl}_{3}$ )

Cesium-137

Chlorine -36

Chromium-51

Chromium (unknown isotopes)

Cobalt-60

Curium

Iodine-131

Iridium-192

Iron -55

Iron-59

Iron (other isotopes)

Neptunium

Nickel-63

Phosphorus -32

Plutonium-238

Plutonium-239

Plutonium-240

Plutonium-241

Plutonium-242

Polonium-210

Promethium-147

Radium-226

Ruthen i um-Rhodium-106

Selenium-75

Sodium-22

Strontium-90

Sulfur -35

Thallium-204

Thorium-232

Thul ium-170

Tritium

Uranium-233

Uranium-234

Uranium-235

Uranium-238

Yttrium-91

Zinc -65

Mixed fission products

Mixed activation products

Unidentified beta/gamma 
Table 10. (continued)

Metals

Aluminum
Beryllium
Carbon steel
Copper
Iron
Lead
Lithium
Magnesium
Mercury
Molybdenum
Platinum
Potassium (as $\mathrm{NaK}$ )
Sodium (metal and $\mathrm{NaK}$ )
Stainless steel
Tantalum
Tin
Yttrium (as $\mathrm{Y}_{2} \mathrm{O}_{3}$ )
Zircaloy
Zirconium
Zinc

Inorganics

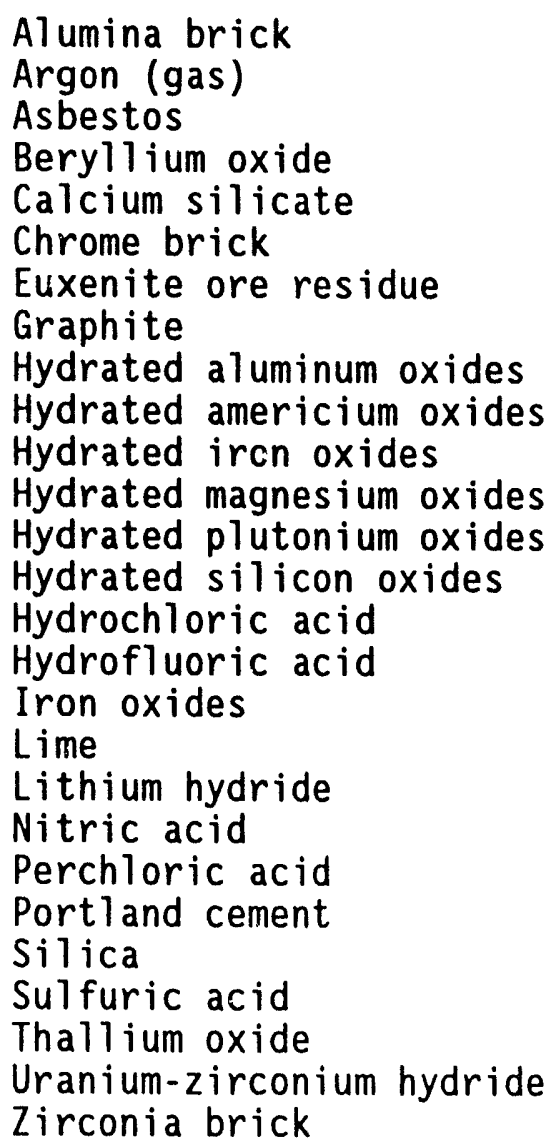


Table 10. (continued)

Salts
Barium carbonate
Barium fluoride
Iron chlorides
Potassium nitrate
Sodium chloride
Sodium nitrate
Thorium fluoride
Uranium fluoride
Radium salts
Metal chlorides

Organics

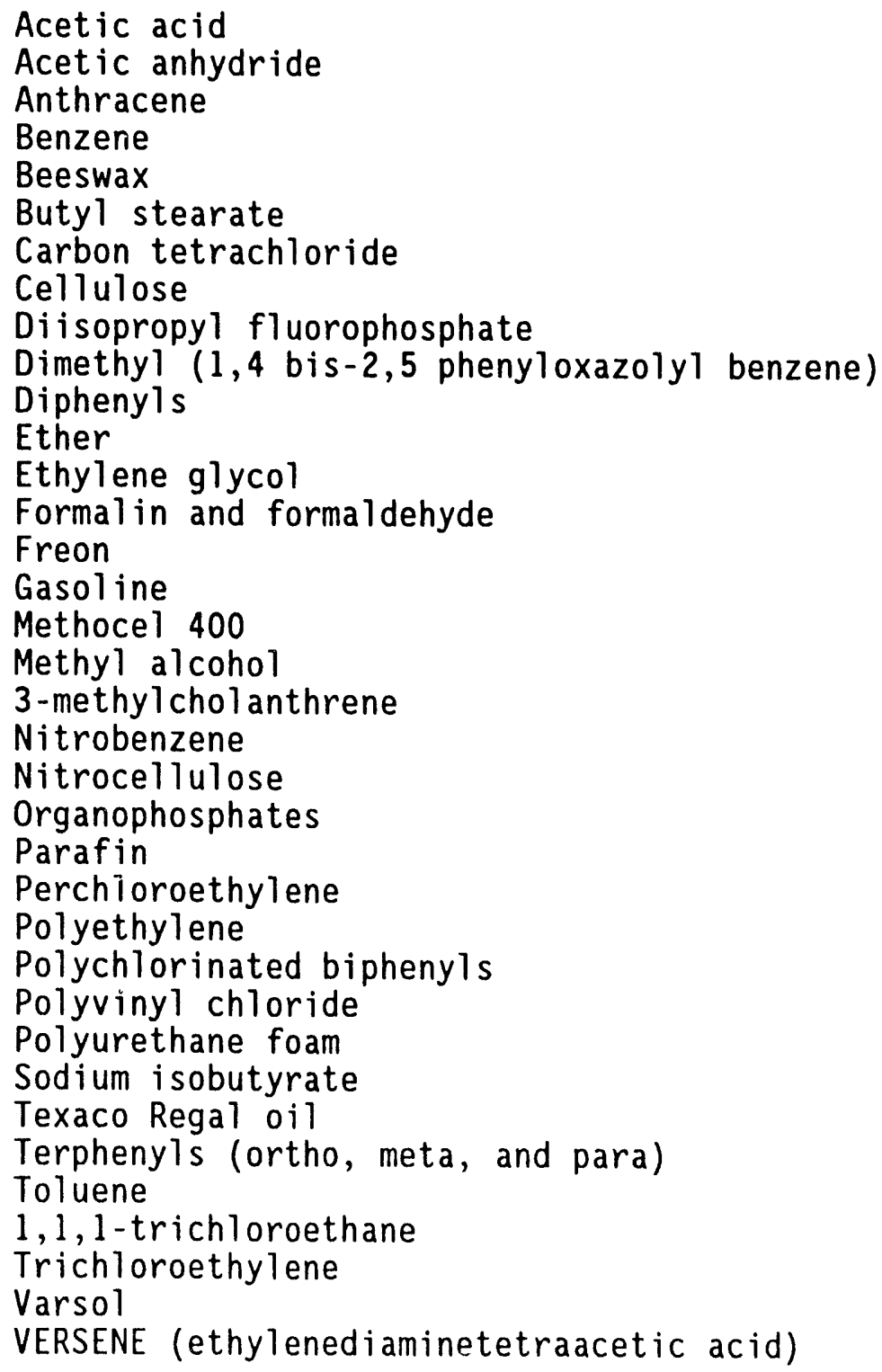


Table 10. (continued)

Miscellaneous oils:
Gearbox oil
Hydraulic oil
Machining oils
Spindle oil
Unidentified:
acids
alcohols
amino acids
esters
insecticides
plastics
proteins
pyrimidines
solvents


Table 11. Weight and volume fractions of wastes stored at the RWMC (Edinborough, 1990)

\begin{tabular}{|c|c|c|c|c|c|}
\hline & Category & Codes & $\begin{array}{l}\text { Weight } \\
\text { Fraction }\end{array}$ & $\begin{array}{l}\text { Volume } \\
\text { Fraction }\end{array}$ & $\begin{array}{l}\text { Density } \\
\left(1 \mathrm{~b} / \mathrm{ft}^{3}\right)\end{array}$ \\
\hline & Combustibles & 40 & 0.201 & 0.42 & 17.73 \\
\hline & Sludge & 36 & 0.327 & 0.18 & 67.22 \\
\hline & Unknown/unclassifiable & 21 & 0.097 & 0.15 & 24.87 \\
\hline & Metals & 15 & 0.222 & 0.086 & 95.87 \\
\hline & Mixed waste & 22 & 0.0389 & 0.073 & 19.86 \\
\hline & $\begin{array}{l}\text { Concrete, brick, } \\
\text { particulates }\end{array}$ & 38 & 0.0791 & 0.045 & 65.70 \\
\hline & Nonmetals and glass & 18 & 0.0284 & 0.041 & 25.95 \\
\hline & Low level & 7 & 0.00389 & 0.005 & 31.81 \\
\hline & Remote handled & 2 & 0.000961 & 0.001 & 25.31 \\
\hline & NonTRU & 1 & 0.00133 & 0.001 & 47.87 \\
\hline & Salts & 11 & 0.000691 & 0.0007 & 39.37 \\
\hline $\begin{array}{l}\text { a. } \\
\text { same }\end{array}$ & \multicolumn{5}{|c|}{$\begin{array}{l}\text { Weight and volume fractions of the buried TRU wastes are assumed to be } \\
\text { as that given for the stored TRU wastes. }\end{array}$} \\
\hline
\end{tabular}


Table 12. Waste container types, numbers, and total volumes for selected pits at the SDA (Guay, 1989)

\begin{tabular}{|c|c|c|c|}
\hline Pit No. & Container Type & No. of Containers & $\begin{array}{c}\text { Volume of } \\
\text { Containers }\left(\mathrm{ft}^{3}\right) \\
\end{array}$ \\
\hline 1 & $\begin{array}{l}\text { Drums } \\
\text { Wooden Boxes } \\
\text { Cardboard Boxes } \\
\text { Other }\end{array}$ & $\begin{array}{r}8,285 \\
152 \\
2,173 \\
2 \\
10,612\end{array}$ & $\begin{array}{r}60,917 \\
8,001 \\
12,869 \\
32 \\
81,819\end{array}$ \\
\hline 2 & $\begin{array}{l}\text { Drums } \\
\text { Wooden Boxes } \\
\text { Cardboard Boxes } \\
\text { Others }\end{array}$ & $\begin{array}{r}34,480 \\
1,048 \\
3,547 \\
443 \\
39,518\end{array}$ & $\begin{array}{r}252,077 \\
75,728 \\
17,960 \\
72,592 \\
418,357\end{array}$ \\
\hline 3 & $\begin{array}{l}\text { Drums } \\
\text { Wooden Boxes } \\
\text { Cardboard Boxes } \\
\text { Other }\end{array}$ & $\begin{array}{r}6,684 \\
201 \\
3,309 \\
62 \\
10,256\end{array}$ & $\begin{array}{r}48,961 \\
10,565 \\
30,774 \\
11,759 \\
102,059\end{array}$ \\
\hline 4 & $\begin{array}{l}\text { Drums } \\
\text { Wooden Boxes } \\
\text { Cardboard Boxes } \\
\text { Other }\end{array}$ & $\begin{array}{r}31,467 \\
624 \\
2,020 \\
268 \\
34,379\end{array}$ & $\begin{array}{r}231,330 \\
68,060 \\
16,617 \\
72,487 \\
388,494\end{array}$ \\
\hline 5 & $\begin{array}{l}\text { Drums } \\
\text { Wooden Boxes } \\
\text { Cardboard Boxes } \\
\text { Other }\end{array}$ & $\begin{array}{r}19,652 \\
919 \\
970 \\
102 \\
21,643\end{array}$ & $\begin{array}{r}144,355 \\
110,831 \\
7,773 \\
23,653 \\
286,612\end{array}$ \\
\hline 6 & $\begin{array}{l}\text { Drums } \\
\text { Wooden Boxes } \\
\text { Cardboard Boxes } \\
\text { Other }\end{array}$ & $\begin{array}{r}13,912 \\
590 \\
3,523 \\
36 \\
18,061\end{array}$ & $\begin{array}{r}102,272 \\
73,918 \\
41,242 \\
6,466 \\
223,898\end{array}$ \\
\hline 9 & $\begin{array}{l}\text { Drums } \\
\text { Wooden Boxes } \\
\text { Cardboard Boxes } \\
\text { Other }\end{array}$ & $\begin{array}{r}3,937 \\
520 \\
1,932 \\
72 \\
6,461\end{array}$ & $\begin{array}{r}28,942 \\
72,735 \\
29,571 \\
19,442 \\
150,690\end{array}$ \\
\hline 10 & $\begin{array}{l}\text { Drums } \\
\text { Wooden Boxes } \\
\text { Cardboard Boxes } \\
\text { Other }\end{array}$ & $\begin{array}{r}27,101 \\
2,311 \\
914 \\
295 \\
30,621\end{array}$ & $\begin{array}{r}189,857 \\
274,048 \\
11,830 \\
63,130 \\
538,865\end{array}$ \\
\hline
\end{tabular}


Table 13. Waste container types, numbers, and total volumes for selected trenches at the SDA (Guay, 1989)

\begin{tabular}{|c|c|c|c|}
\hline Trench No. a & Container Type & No. of Containers & $\begin{array}{c}\text { Volume of } \\
\text { Conta iners } \\
\left(\mathrm{ft}^{3}\right)\end{array}$ \\
\hline 1 & $\begin{array}{l}\text { Drums } \\
\text { Other }\end{array}$ & $\begin{array}{r}3,376 \\
1 \\
3,377\end{array}$ & $\begin{array}{r}16,747 \\
150 \\
16,897\end{array}$ \\
\hline 2 & $\begin{array}{l}\text { Drums } \\
\text { Wooden Boxes }\end{array}$ & $\begin{array}{r}1,045 \\
4 \\
1,049\end{array}$ & $\begin{array}{r}6,761 \\
40 \\
6,801\end{array}$ \\
\hline 3 & $\begin{array}{l}\text { Drums } \\
\text { Wooden Boxes } \\
\text { Cardboard Boxes }\end{array}$ & $\begin{array}{r}1,242 \\
6 \\
1,423 \\
2,671\end{array}$ & $\begin{array}{r}8,655 \\
162 \\
7,115 \\
15,932\end{array}$ \\
\hline 4 & $\begin{array}{l}\text { Drums } \\
\text { Wooden Boxes }\end{array}$ & $\begin{array}{r}2,416 \\
1 \\
2,417\end{array}$ & $\begin{array}{r}17,761 \\
27 \\
17,788\end{array}$ \\
\hline 5 & Drums & $\frac{2,541}{2,541}$ & $\frac{18,176}{18,176}$ \\
\hline 6 & $\begin{array}{l}\text { Drums } \\
\text { Wooden boxes }\end{array}$ & $\begin{array}{r}2,283 \\
1 \\
2,284\end{array}$ & $\begin{array}{r}15,462 \\
13 \\
15,475\end{array}$ \\
\hline 7 & Drums & $\frac{1,497}{1,497}$ & $\frac{10,729}{10,729}$ \\
\hline 8 & $\begin{array}{l}\text { Drums } \\
\text { Cardboard boxes }\end{array}$ & $\begin{array}{r}1,654 \\
793 \\
2,447\end{array}$ & $\begin{array}{r}12,160 \\
3,965 \\
16,125\end{array}$ \\
\hline 9 & $\begin{array}{l}\text { Drums } \\
\text { Wooden boxes } \\
\text { Cardboard box }\end{array}$ & $\begin{array}{r}1,769 \\
1 \\
2 \\
1,772\end{array}$ & $\begin{array}{r}13,008 \\
224 \\
10 \\
13,242\end{array}$ \\
\hline 10 & $\begin{array}{l}\text { Stee } 1 \text { drums } \\
\text { Cardboard boxes }\end{array}$ & $\begin{array}{r}1,236 \\
7 \\
1,243\end{array}$ & $\begin{array}{r}9,089 \\
35 \\
9,124\end{array}$ \\
\hline
\end{tabular}

a. The stored waste in Trenches 1-10 consisted mainly of cardboard boxes from the INEL on-site generators. Intermixed with the on-site boxes were steel drums, wooden boxes, plastic bags, and loose waste. Some Rocky Flats waste is also intermixed. Values reflect the retrieved waste removed. 
Table 14. Special waste considerations buried in pits at the SDA (Card, 1977)

\begin{tabular}{|c|c|}
\hline Pit No. & Comments \\
\hline 1 & $\begin{array}{l}\text { Pit reopened in October, } 1961 \text {, for disposal of some waste } \\
\text { from the SL-1 reactor incident. Waste contained } \\
\text { approximately } 120 \text { Curies of MFP. Highest radiation reading } \\
\text { recorded was } 10 \mathrm{R} / \mathrm{h} \text { at contact. This waste is probably } \\
\text { limited to the western end of the pit. }\end{array}$ \\
\hline 2 & $\begin{array}{l}\text { Large amounts of beta-gamma contaminated waste disposed with } \\
\text { the TRU drums and boxes. This waste includes reactor } \\
\text { shielding }(36,000 \text { 1b), an aluminum heat exchanger }(20,000 \\
\left.\text { 1b), drums with various contents, large (150 } \mathrm{ft}^{3}\right) \text { concrete } \\
\text { blocks contaminated with MFP, and other items. Also this } \\
\text { pit contains contaminated material from the cleanup of the } \\
\text { SL-1 incident. This pit was flooded in 1962, prior to } \\
\text { closure. }\end{array}$ \\
\hline 3 & $\begin{array}{l}\text { NonTRU boxes from various on-site sources buried in this } \\
\text { pit. These boxes apparently contain MFP. Six boxes (12,000 } \\
\text { to } 14,000 \text { lb each) of intermediate-level waste ( } 55-g a l \text { drum } \\
\text { centered in a box, and the box was then filled with concrete } \\
\text { shielding) buried at unknown locations in pit. SL-1 } \\
\text { incident cleanup waste also buried in this pit. }\end{array}$ \\
\hline 4 & $\begin{array}{l}\text { MFP wastes intermixed with TRU wastes; locations are not } \\
\text { clearly recorded (probably randomly dumped into the pit). } \\
\text { Non-TRU waste (containers, scrap lumber, concrete, } \\
\text { miscellaneous equipment, scrap metal, valves, and piping) } \\
\text { generally confined to the westernmost } 91 \mathrm{~m} \text { of the pit. }\end{array}$ \\
\hline 5 & $\begin{array}{l}\text { Burial location for some of the wastes may be in error. A } \\
\text { good possibility exists that some of the wastes may actually } \\
\text { be outside of recorded pit boundaries. }\end{array}$ \\
\hline 6 & $\begin{array}{l}\text { Drums and boxes were not segregated during burial. A large } \\
\text { number of boxes containing contaminated empty drums are } \\
\text { buried in this pit. }\end{array}$ \\
\hline 9 & $\begin{array}{l}\text { Drums and boxes were not segregated. A large number of } \\
\text { boxes containing contaminated empty drums are buried in pit. }\end{array}$ \\
\hline 10 & $\begin{array}{l}\text { Contains large number of boxes of contaminated empty drums, } \\
\text { but the number of drums per box is not known. This pit was } \\
\text { flooded in the spring of } 1969 \text {, before it was closed. }\end{array}$ \\
\hline
\end{tabular}


Table 15. Volumes of organic wastes shipped from RFP to INEL (Kudera, 1987)

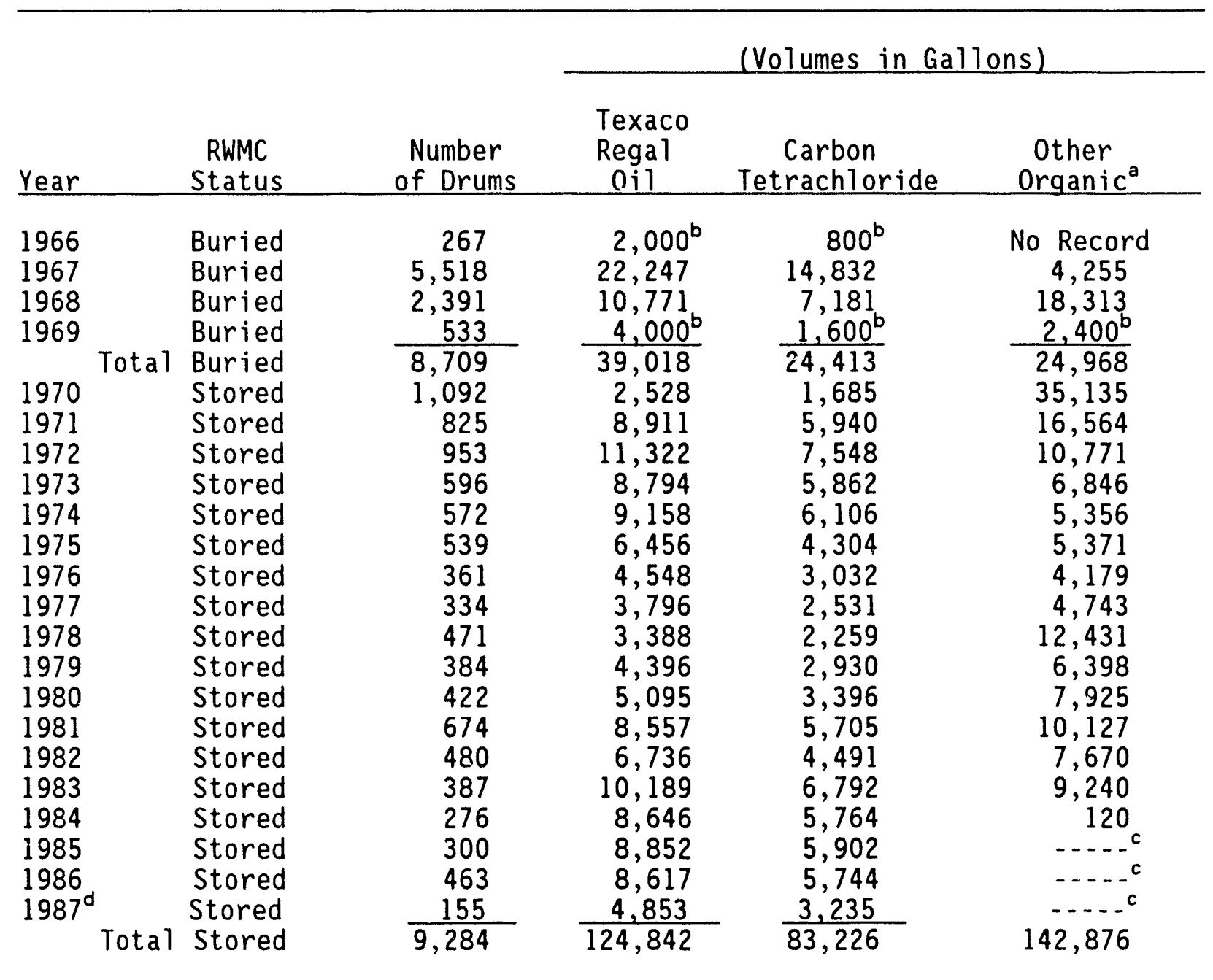

a. Mostly 1,1,1-trichloroethane, trichloroethylene, perchloroethylene, and used 0 i1.

b. Data estimated.

c. In 1984, this category of organic wastes were processed separately and shipped to the Nevada Test Site as low-level wastes.

d. January to June 1987. 
Table 16. Estimates of metal content in selected pits and trenches at the SDA (Garcia et al, 1989)

\begin{tabular}{|c|c|c|c|}
\hline $\begin{array}{l}\text { Waste } \\
\text { Location }\end{array}$ & $\begin{array}{c}\text { Total Weight } \\
\text { of Waste } \\
(\mathrm{kg})\end{array}$ & $\begin{array}{c}\text { Maximum Metal } \\
\text { Weight } \\
(\mathrm{kg})\end{array}$ & $\begin{array}{c}\text { Minimum Metal } \\
\text { Weight } \\
(\mathrm{kg})\end{array}$ \\
\hline Pit 1 & 337,300 & 269,840 & 16,865 \\
\hline Pit 2 & $7,264,000$ & $5,811,200$ & 363,200 \\
\hline Pit 3 & 823,500 & 658,800 & 41,175 \\
\hline Pit 4 & $5,539,000$ & $4,431,200$ & 276,950 \\
\hline Pit 5 & $2,968,000$ & $2,374,400$ & 148,400 \\
\hline Pit 6 & $2,672,000$ & $2,137,600$ & 133,600 \\
\hline Pit 9 & $1,357,707$ & $1,086,166$ & 67,885 \\
\hline Pit 10 & $6,148,000$ & $4,918,400$ & 307,400 \\
\hline Trench 1 & 274,500 & 219,600 & 13,725 \\
\hline Trench 2 & 123,700 & 98,960 & 6,185 \\
\hline Trench 3 & 196,500 & 157,200 & 9,825 \\
\hline Trench 4 & 267,600 & 214,080 & 13,380 \\
\hline Trench 5 & 347,200 & 277,760 & 17,360 \\
\hline Trench 6 & 305,000 & 244,000 & 15,250 \\
\hline Trench 7 & 198,800 & 159,040 & 9,940 \\
\hline Trench 8 & 208,000 & 166,400 & 10,400 \\
\hline Trench 9 & 179,300 & 143,440 & 8,965 \\
\hline Trench 10 & 110,500 & 88,400 & 5,525 \\
\hline TOTAL & $27,962,900$ & $22,370,320$ & $1,398,145$ \\
\hline
\end{tabular}

a. Maximum metal weight was assumed to be $80 \%$ (worst-case scenario) of the total weight of the waste. Minimum metal weight was assumed to be $5 \%$ of the total weight of the waste. 
Radiological wastes of primary concern at the SDA include TRU wastes and LLW, which include mixed-fission products (MFP) and mixed activation products (MAP). In addition, some high radiation level wastes were disposed of in trenches at the SDA (Vigil, 1989). Currently, the TRU wastes are felt to be of most concern as a threat to human health and the environment. The amount of TRU nuclides originating from RFP buried in the SDA from 1954 to 1970 is $381.3 \mathrm{~kg}$, corresponding to 241,531 Curies (Lee, 1971) (Garcia and Knight, 1989). In addition, $203,322.5 \mathrm{~kg}$ (74.7 Curies) of various uranium isotopes were also shipped from RFP to the SDA (Lee, 1971) (Garcia and Knight, 1989). Following the retrieval efforts in Pits 11 and 12, approximately 116 boxes of TRU wastes remain in these pits (Horton, 1988). Assuming an average size of $4 \times 4 \times 7 \mathrm{ft}$ for boxes received from RFP, the corresponding TRU waste volume equals $17,359 \mathrm{ft}^{3}$. According to Horton (1988), Trenches 16 through 54 contain a total of $4,367 \mathrm{ft}^{3}$ of TRU wastes (potentially mixed with MFP) received from on-site waste generators. For LLW, a total of 583,000 Curies (which includes mixed fission and activation products) were buried in the SDA with the TRU wastes (Vigil, 1989); it is not clear, however, if this amount includes only INEL-generated wastes or both INEL and off-site generated $L L W$. (In addition, because TRU and LLW wastes were not completely segregated prior to 1970, TRU wastes may also be present in Trenches 11 through 15; this cannot, however, be substantiated without a review of the shipping records for these trenches.)

The disposal records include a variety of sludges having been disposed in the SDA. These sludges include process sludges from RFP (74 series sludges), sewage sludge, and miscellaneous other sludges. The greatest volume of sludges were those received from RFP (Vigil, 1989) and included the following.

- $\quad 741$ sludge is a wet sludge produced from treating aqueous process wastes, such as ion-exchange column effluents, distillates, and caustic scrub solutions. The caustic scrub solutions contain ferric sulfate, calcium chloride, magnesium sulfate, and flocculating agents. These chemicals form a precipitate of the 
hydrated oxides of iron, magnesium, aluminum, silicon, plutonium, and americium and may contain low concentrations of beryllium.

- $\quad 742$ sludge is a wet sludge produced from the treatment of all other plant radioactive and/or chemical contaminated wastes and further treatment of 741 sludge. This type of sludge may also contain mercury, lithium batteries, and small amounts of contaminated mercury in pint bottles. The same treatment chemicals were used as in the 741 sludge and the same precipitates formed.

- $\quad 743$ sludge was produced from treatment of liquid organic wastes. The sludge waste consists of such materials as degreasing agents (mostly trichloroethane), lathe coolant (60\% Texaco Regal $0 i 1$ and $40 \%$ carbon tetrachloride), and hydraulic oils. Other organic wastes included trichloroethylene, tetrachloroethylene, gearbox and spindle oils, and trace amounts of miscellaneous organic laboratory wastes (e.g., organophosphates and nitrobenzene). There are also some unknown volumes of oil containing PCBs that were processed with this type of sludge.

- $\quad 744$ sludge resulted from processing liquid waste not compatible with the 741 and 742 processes due to their plutonium complexing nature. The complexing chemicals included some alcohols, organic acids, and VERSENES (trade name for chelating agents containing ethylenediaminetetraacetic acid). These were added to Portland cement to solidify the wastes.

- 745 sludge is a salt waste originating from evaporation of liquid waste impounded in solar evaporation ponds at the RFP. The salt is estimated to consist of $60 \%$ sodium nitrate, $30 \%$ potassium nitrate, and $10 \%$ miscellaneous material. 


\section{MIGRATION OF WASTES}

In recent years, data have been gathered documenting the migration of some waste constituents away from the SDA (EG\&G Idaho, 1989). In particular, several organic compounds (including carbon tetrachloride, chloroform, tetrachloroethylene, 1,1,1-trichloroethylene, and trichloroethylene) have been detected at elevated levels in the sedimentary interbeds beneath the RWMC and in wells near the SDA (Hodge et al, 1989). Radionuclides (including Pu-238, $\mathrm{Pu}-239, \mathrm{Pu}-240, \mathrm{Am}-241, \mathrm{Cs}-137$, and $\mathrm{Sr}-90$ ) have been detected in the soils and in sedimentary interbeds to a depth of $240 \mathrm{ft}$ beneath the RWMC (Hodge et al, 1989). Table 17 describes the migration of contaminants from the SDA into the surrounding media. Figures 2 and 3 present diagrams of the migration pathways for radionuclides and hazardous contaminants and for volatile organic chemical contaminants, respectively. 
Table 17. Summary of Contaminants and Environmental Media of Concern (Hodge et al, 1989)

\begin{tabular}{|c|c|c|c|}
\hline \multirow{2}{*}{$\begin{array}{l}\text { Environmental } \\
\text { Medium }\end{array}$} & \multicolumn{3}{|c|}{ Presence of } \\
\hline & Organics & Inorganics & Radionuclides \\
\hline \multirow{4}{*}{$\begin{array}{l}\text { Air } \\
\text { Surface water } \\
\text { So } 11 \\
\text { Bedrock } \\
\text { Interbeds } \\
\text { Groundwater }\end{array}$} & $x$ & $x$ & $\mathbf{a}$ \\
\hline & $\begin{array}{l}X \\
a\end{array}$ & $\begin{array}{l}\mathbf{a} \\
\mathbf{a}\end{array}$ & $\underset{a}{X}$ \\
\hline & $a$ & $x$ & $x$ \\
\hline & $x$ & $\ddot{x}$ & $\hat{x}$ \\
\hline \multicolumn{4}{|c|}{$\begin{array}{l}\text { Sampling results detected contaminant presence at levels below } \\
\text { environmental concern, but worthy of note. }\end{array}$} \\
\hline
\end{tabular}




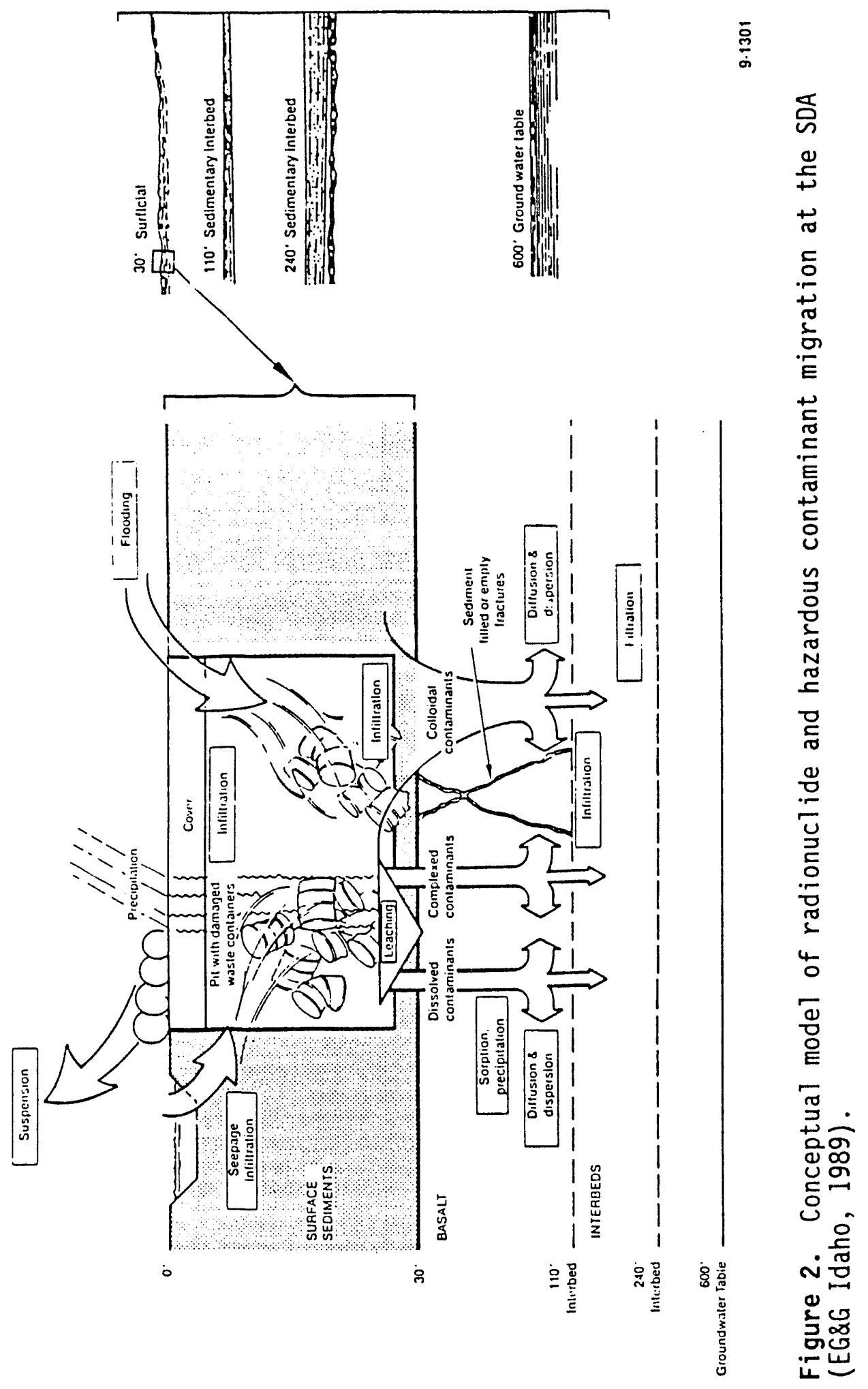




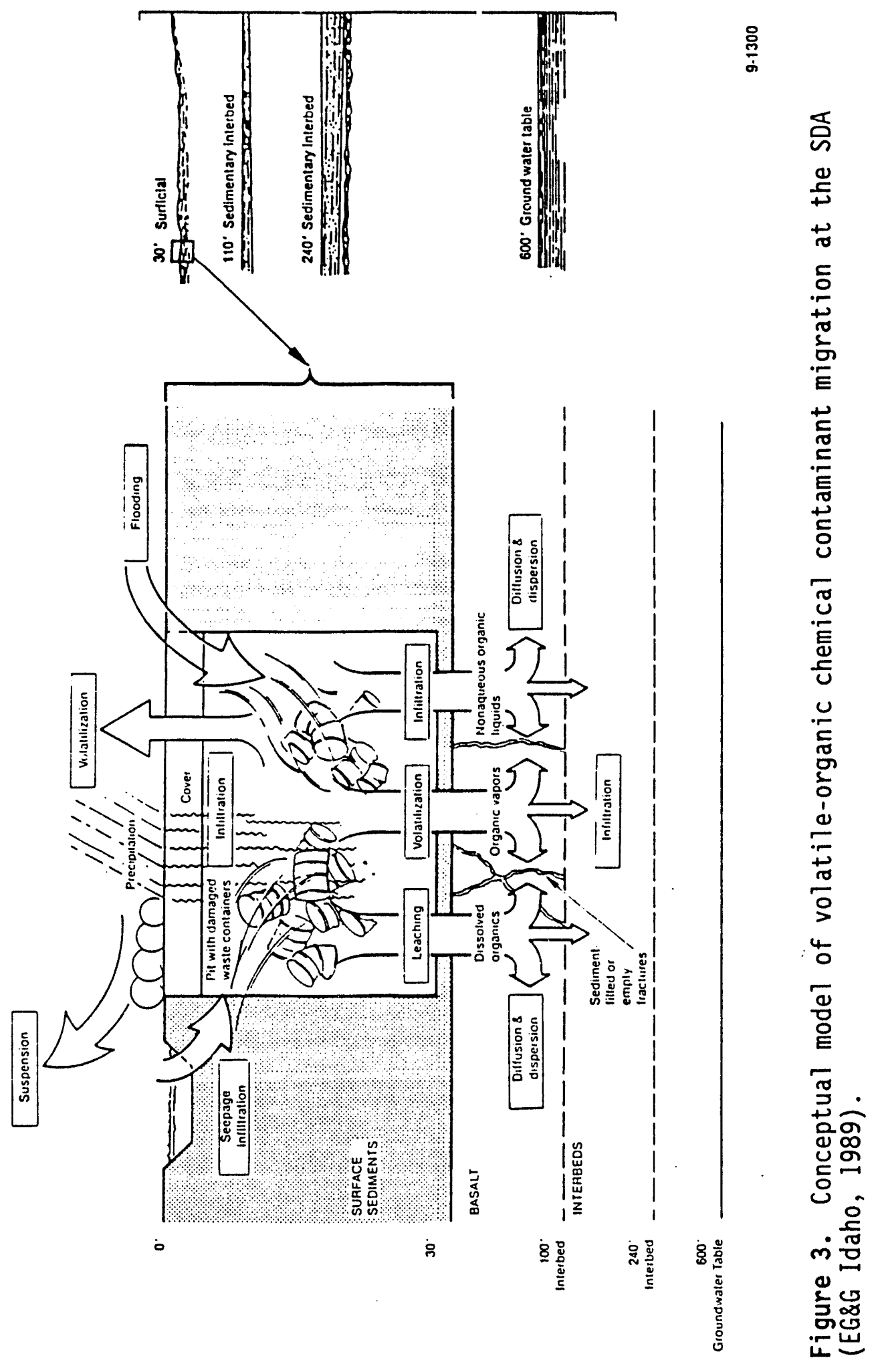




\section{ASSUMPTIONS}

In order to compile the summary information presented in this document, the following assumptions were made.

- Earlier retrieval efforts (Thompson, 1972) (McKinley and McKinney, 1978) (Bishoff and Hudson, 1979) discovered a large number of breached drums and decayed cardboard and wooden boxes. Because it has been 13 years since these efforts took place and because the wastes had been in place for less than 10 years at the time of these retrieval efforts, the majority of the waste containers are now assumed to have been breached or otherwise somewhat deteriorated. Degradation of the waste containers, however, may be offset somewhat by the internal plastic packaging, which may still retain its integrity.

- Based on the above assumption, and in order to provide conservative estimates, the contaminants are assumed to have leaked or migrated out into the surrounding soils. All underburden and interstitial soils associated with Pits 1 through 6, 9, and 10 and Trenches 1 through 10 are assumed to be TRU contaminated. As a result of discoveries made during the earlier retrieval operations (McKinley and Mckinney, 1978) the tup $18 \mathrm{in}$. of overburden in the pits and trenches are assumed to be uncontaminated; the remainder of the overburden, however, is assumed to be contaminated.

- Because these wastes were disposed during the period 1952 to 1970 , the corresponding definition of TRU wastes was used (see footnote page 2). 
- Although no records exist for waste shipments to the SDA originating from INEL (earlier known as the National Reactor Testing Station NRTS) sources prior to 1960 and because of the activities being performed at the different facilities (RFP and INEL), the vast majority of the TRU wastes are assumed to have originated off-site. Due to the types of operations that were conducted at the INEL, the majority of LLW is assumed to have come from on-site generators. The pits 1 through 6, 9, and 10 generally contain more RFP TRU waste than INEL LLW waste; the opposite is true for Trenches 1 through 10 (Vigi1, 1989).

TRU wastes were iimited to the pits and trenches considered in this document. However, containers of waste may be located outside of established pit/trench boundaries, particularly near Pit 5 (Card, 1977) and Pit 2 (Thompson, 1972).

- Waste volumes given do not, with the exception of Pit 9 metal contents, include the volume of container/packaging materials. This is because volumes of metal drums, wood, and plastics may be considerable (wood was often used to shore bulky waste items in the wooden boxes during shipment to prevent movement during shipping, and most items were wrapped in at least a single layer of plastic prior to disposal). It is unclear if the volumes of wastes included materials (e.g., lead sheeting) used for shielding in the waste containers and whether these volumes are significant.

Mixed wastes were not considered separately from the other organic and TRU wastes.

- The description and quantities of wastes disposed at the SDA are not expected to change significantly from those presented in this document following a more detailed review of the available literature and shipping records. This review is pending. 


\section{DISCREPANCIES}

Although estimates of the combined volume of wastes and contaminated soils in the TRU waste pits and trenches at the SDA include $7.7 \mathrm{million} \mathrm{ft}^{3}$

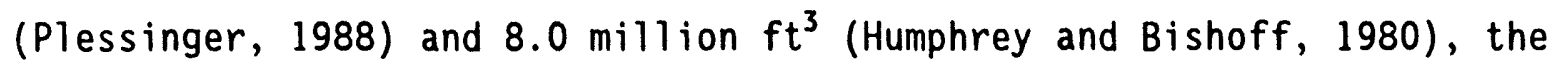
degree of detail and method of estimating this volume provided by Guay (1989) lends greater credence to the estimate quoted in this document (e.g., 12.1

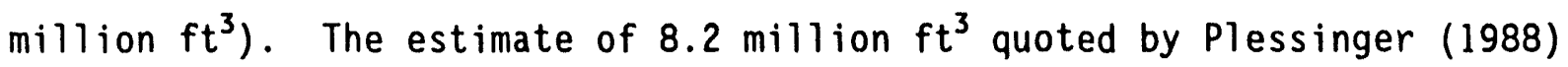
and attributed to Humphrey and Bishoff appears to be in error. In addition, Plessinger's estimate does not include underburden volume; ai hough Humphrey and Bishoff's estimates do include underburden, their calculations are not sufficiently documented to permit comparison. Guay's estimate includes not only overburden and underburden, but also presents a breakdown of volumes by pit and trench based on individual basalt and soil surface elevations and takes into account subsidence and compaction of waste containers in trenches. A large portion of these discrepancies may be due to additional overburden placed during subsequent SDA regrading operations.

Guay (1989) cites a number of references that give a total waste volume (from RFP, other off-site generators, and NRTS/INEL generators) buried at the SDA from 1952 through 1970 as 4.16 million $\mathrm{ft}^{3}$. In his calculations of waste container volume buried in the TRU contaminated portions of the SDA, Guay gives a total of 2.32 million $\mathrm{ft}^{3}$. Other estimates of total waste volume include: 2.67 million $\mathrm{ft}^{3}$ (Humphrey and Bishoff, 1980) (Vigil, 1989), 2.34 million $\mathrm{ft}^{3}$ (Garcia et al, 1989), 2.7 million $\mathrm{ft}^{3}$ (as both TRU and beta-gamma wastes) (Hinckley, 1981), and 2.3 million $\mathrm{ft}^{3}$ (McKinley, 1978). It is assumed that these numbers also represent wastes buried in the TRU contaminated portions of the SDA. Although some of these numbers may have since been discredited in subsequent efforts, they are provided to demonstrate the wide discrepancies that exist in estimates of waste amounts buried at the SDA. Obviously, further work is necessary to refine these numbers and explore this discrepancy. 
Differences also exist in the estimated amounts of TRU radionuclides present at the SDA. ORNL (1989) presents a total mass of TRU nuclides (of $\mathrm{DOE} /$ defense origin) of $357 \mathrm{~kg}$ (as of 1988). Barnes et al (1989) cites the $\mathrm{Pu}^{239}$ content of the buried wastes as being $338 \mathrm{~kg}$. Lee (1971; claims that $381.3 \mathrm{~kg}$ of TRU nuclides were shipped from the RFP to the SDA during the period 1954 to 1970; of this amount, $343.3 \mathrm{~kg}$ were $\mathrm{Pu}^{239}$. It is not clear whether the numbers cited by ORNL and Barnes et al include TRU nuclides generated on the INEL Site or by off-site generators other than RFP. The reduction in TRU nuclides resulting from decay during the intervening period (1970 to 1988/1989) may not account for the entire discrepancy, particularly if TRU wastes from generators other than the RFP were received at the SDA. Again, further work is necessitated to determine the amount of TRU nuclides present in buried wastes at the SDA. Lee (1971) has been cited in this report because it is not only the more conservative number, but also because this number was supplied directly from RFP, the major generator of TRU wastes.

This report was developed through the review of a large number of existing documents that present a great deal of information on the waste types, quantities, and locations. The information selected for inclusion in this report, however, was chosen because it appeared to be the most valid and defensible of the information contained in the reports reviewed in the time allowed. An example of this is Card (1977), which contains a series of diagrams of the TRU-containing pits showing general waste disposal locations; these diagrams were not included in this report. This is because the source of the information used to develop these drawings is not felt to be entirely accurate. Thus, this report represents what is felt to be the best available information at the time of release. As more information becomes known, and as more validity is afforded to the existing information not included in this report, this report will be revised. 


\section{PROPOSED FUTURE ACTIONS}

In light of the questions arising from the assumptions made and discrepancies identified during preparation of this document, several additional efforts to reduce the uncertainties regarding buried wastes (including locations, contaminants, conditions, and quantities) are proposed to be conducted by the staff of the Technology Demonstration group at EG\&G Idaho.

- Identify and obtain existing site characterization documents and reports from earlier retrieval efforts. This has, to a large extent, already been accomplished, and files containing this information have been set up.

- Identify current site characterization efforts within other organizations, such as Waste Area Group-7 (WAG-7). Although the extent of current site characte ization efforts has not been determined, initial contacts with personnel involved with identified efforts have been made. In these cases, agreement has been reached regarding the need for a coordinated site characterization effort, such as that currently proposed.

- Review existing information to identify primary information sources, determine data quality, ensure consistency, and establish a valid foundation for future efforts.

- Compile waste amounts, waste types, and identification of waste disposal locations from the existing documents reviewed above.

Review existing shipping records dating from the period of burial of RFP wastes at the SDA to determine types, dates, and volumes of wastes shipped from RFP to INEL. This effort is currently being performed by WAG-7; however, nc coordination in this effort is apparent and the time frame for completion does not coincide with Waste Technology 
Development Department milestones. We propose that these records be reviewed by personnel having strong technical backgrounds with the purpose of updating the existing Radioactive Waste Management Information System database and validating existing information on waste volumes and disposal locations.

Emphasize attempts to verify the locations of "special case" wastes and to establish a confidence level with relation to the existing information sources. The intent will be to utilize current, state-ofthe-art geophysical techniques, in addition to the existing waste disposal records, to determine the locations of these special case wastes and to define the boundaries of the pits and trenches.

- Reconstruct, to the degree attainable, shipping records for on-site generators of wastes buried at the SDA. These records were destroyed during previous "housekeeping" efforts, but can be reconstructed to a limited extent from knowledge of the work processes and research activities generating the wastes. This effort has been begun by members of the Risk Assessment unit under Bob Nitschke, but is currently on hold pending budget allocations and anticipated workload.

- Estimate current radionuclide inventories in buried wastes at the SDA by applying rate of decay algorithms to the reviewed and verified radionuclide estimates resulting from the proposed effort. 


\section{REFERENCES}

Barnes, C.M., L.C. Brown, J.T. Brown, (1989), Investigation of Plutonium-239 Recovery from RWMC TRU Waste, WM-PD-89-011.

Bishoff, J.R., R.J. Hudson, (1979), Early Waste Retrieval, Final Report, TREE1321 .

Card, D.H., (1977), History of Buried Transuranic Waste at INEL, WMP 77-3.

Edinborough, C.R., (1990), Processing Criteria for TRU Removal from RWMC

Stored Waste, ERDP 2802.

EG\&G Idaho, (1989), Remedial Investigation/Feasibility Study Work Plan for the Subsurface Disposal Area, Radioactive Waste Management Complex at the INEL, Draft, EGG-WM-8776.

Garcia, E.C., J.L. Knight, (1989), Detailed Estimate of Radioactive Material Contents for Pit 9, BWP-ISV-004.

Garcia, E.C., S.M. Thurmond, J.L. Knight, (1989), Estimate of Metal Content of SDA, BWP-ISV-005.

Guay, K.P., (in preparation), Preparation of Soil Distribution in Trenches 1 10 , and Pits $1-6,9$, and 10, BWP-ISV-011.

Hinckley, J., (1981), Alternatives for Long-Term Management of Contaminated Soil Associated with Buried Transuranic Waste at INEL, WM-F1-81-025.

Hodge, V., C. Cross, W. Ellis, et al, (1989), Preliminary Remedial Action Objectives and Remediation Technologies for the Subsurface Disposal Area, Preliminary Draft Report, EGG-WM-8434.

Horton, R.B., (1988), Identification of Buried TRU Pits/Trenches at the RWMC, RWMC - 320/BWP-8.

Humphrey, T.G., J.R. Bishoff, (1980), Letter to T.H. Smith, Quantity of Contaminated Soil, TGH-3-80.

Kudera, D.E., (1987), Estimate of Rocky Flats Plant Organic Wastes Shipped to the RWMC, EG\&G Idaho, Inc.

Lee, W.H., (1971), Letter to H.F. Soule, Rocky Flats Solid Waste Shipped to NRTS.

McKinley, K.B., (1978), Background Information, Objectives, and Comparison Criteria for Selection of a Retrieval Concept, PR-W-78-009.

McKinley, K.B., J.D. Mckinney, (1978), Initial Drum Retrieval, Final Report, TREE-1286. 
ORNL (Oak Ridge National Laboratory), (1989), Integrated Data Base for 1989:

Spent Fuel and Radioactive Waste Inventories, Projections, and

Characteristics, Oak Ridge National Laboratory, D0E/RW-0006, Rev. 5.

Plessinger, M.P., (1988), Volume of Transuranic (TRU) Waste and TRU

Contaminated Soil Subject to BWP Retrieval Operations, BWP-4.

Thompson, R.J., (1972), Solid Radioactive Waste Retrieval Test, Allied

Chemical Corp., ACI-120.

Vigil, M.J., (1989), Subsurface Disposal Area (SDA) Waste Identification (1952

- 1970 Emphasis), EGG-WM-8727. 

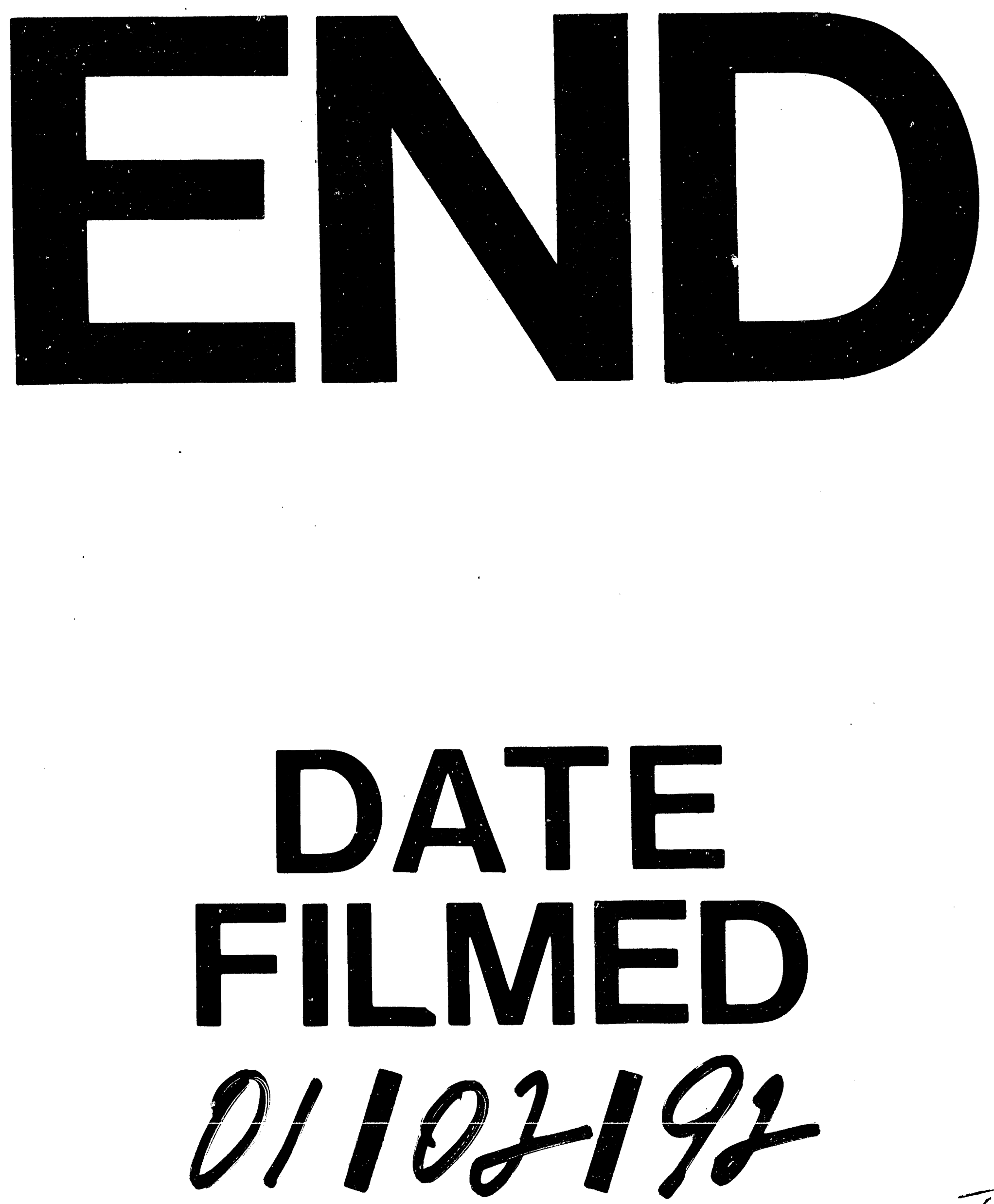


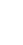

